\title{
Prihodnost dela - prihodnost učenja
}

Delo določa naše učenje in učenje določa naše delo. Po obdobju taylorizma so postale delovne naloge zelo kompleksne in predvsem raznovrstne. V nasprotju s časi masovne proizvodnje zahteva sedanji trg unikatne in inovativne proizvode ter storitve. Interesov kupcev in poslovnih strank ni mogoče več zadovoljiti s standardnimi storitvami, saj zahtevajo prilagodljivost na zelo visoki ravni.

Vsakdo v delovni organizaciji je zavezan, da s svojim strokovnim delom $k$ tej novi paradigmi doda svoj del. Tako danes delo od nas zahteva veliko več prizadevanj in sposobnosti kot nekoč. Obvladovati moramo različne poklicne spretnosti, kot so dopolnjevanje strokovnih znanj, obvladovanje in selekcioniranje informacij, načrtovanje lastnega dela, odločanje, prevzemanje odgovornosti, timsko delo, nenehno zagotavljanje kakovosti, primerna komunikacija ...

Naštete poklicne spretnosti izhajajo iz logike poklicne naloge. Enako nastajajo tudi izobraževalne potrebe. Učenje prihodnosti je definirano na temelju dela in ne več s sistematičnim kurikulumom ali dolgoročnim učnim načrtom. Spremembe so namreč tako hitre in prihodnost tako nejasna, da se je tvegano učiti »na zalogo in si zastaviti dolgoročni učni načrt. Po drugi strani pa je učenje potrebno povsod, kjer se dogajajo spremembe.

In kako se na novo paradigmo odzivajo slovenska podjetja? Opozorila bi predvsem na tri zelo očitna neskladnja med retoriko in realnostjo izobraževanja $v$ slovenskem poslovnem okolju.

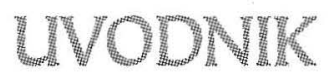

Prvič, retorično vsi prisegamo na vseživljenjsko izobraževanje. Če si ogledamo številke,

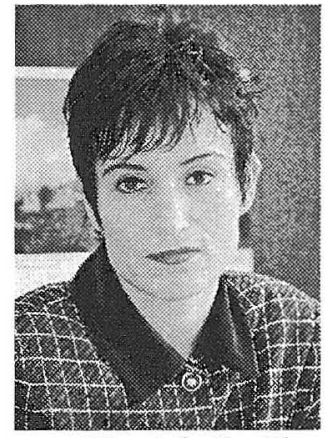

mag. Daniela Brečko ugotovimo, da presedi posameznik od vrtca do končane fakultete pri pouku povprečno 21. 420 ur ali 892 dni in pol. Z vstopom v svet dela pa se številke povsem spremenijo. $V$ slovenskem poslovnem okolju velja za velik uspeh, če posveti organiziranim oblikam izobraževanja 40 ur na leto. To je vsekakor premalo za kakovostno bivanje $v$ tretjem tisočletju, ki so ga mnoge znane osebnosti označile kot tisočletje učenja. Za primerjavo povejmo, da nameni japonski poslovnež učenju povprečno dve uri na dan.

Drugič, izkušnje kažejo, da podjetja največ izobražujejo v času, ko jim je poslovno okolje naklonjeno in dobro poslujejo. To je samo po sebi seveda vredno pohvale, toda vprašati se moramo, ali je tudi ekonomično. Logika poslovnega sveta temelji na ekonomičnosti, kar bi z drugimi besedami pomenilo, da mora tudi izobraževanje izkazati določene, merljive učinke. V takšnih »zlatih « časih je izobraževanje velikokrat tudi nagrada za dobro opravljeno delo, in ne dejanska potreba po pridobitvi novega znanja. To seveda ni slabo, saj vsi vemo, da ima izobraževanje tudi velik motivacijski naboj. Toda ko se »zlati« časi prevesijo v črni petek, ponavadi najprej zmanjka denarja za izobraževanje. In tedaj se podre poslovna logika. Z novim znanjem bi podjetje vsekakor prej in verjetneje premagalo krizo. Toda denarja za izobraževanje preprosto ni in vse velike besede o pomembnosti znanja naletijo pri vodstvu podjetja na gluha ušesa. 
In tretjič, iz zornega kota učenja so odrasli, ki so se pripravljeni in sposobni učiti se vse življenje, cenjeni člani družbe. Na srečo je že veliko podjetij spoznalo, da njihova resnična vrednost ni kapital ali tehnologija, temveč možgani zaposlenih. Če je to dobra plat, pa je slaba ta, da se vsi odrasli niso sposobni in pripravljeni učiti se ali za to preprosto nimajo možnosti. Posamezniki, ki se tako ali drugače ne zmorejo učiti se vse življenje, so tudi nesposobni izboljšati svoj socialni in ekonomski status. Pri tem se seveda postavi še vprašanje, ali je »neizobraževanje njihova zavestna izbira ali preprosto nimajo možnosti.

Domala vse svetovne raziskave so potrdile, da imajo več možnosti za izobraževanje bolj izobraženi in ekonomsko bolje stoječi posamezniki. Tudi v slovenskih podjetjih je skoraj enako. Tisti, ki znanje že imajo, ga še poglabljajo, največkrat jih na izobraževanje pošlje podjetje, ki jim izobraževanje večinoma tudi plača. Tisti, ki bi znanje nujno potrebovali, pa velikokrat ostanejo praznih rok. Treba pa je seveda dodati še to, da je interes za izobraževanje pri bolj izobraženih neprimerno večji v primerjavi z manj izobraženimi, $k i$ izobraževanje pogosto doživljajo kot prisilo ali celo kazen.

Kaj je torej narobe z izobraževanjem za potrebe dela? Ali ne znamo motivirati ljudi za učènje ali pa nam to pravzaprav ustreza. $\check{C}$ e smo rekli, da delo določa učenje in učenje delo, bi lahko rekli tudi, da s tem ko onemogočamo dostop do znanja zaposlenim, ki so nižje na hierarhični lestvici, pravzaprav zaviramo razvoj delovnih procesov in tako posredno ohranjamo tudi hierarhično zgradbo delovnih organizacij. Na koncu pa se moramo vprašati tudi, ali to počnemo zavestno ali pa nam preprosto manjka znanja in moči, da bi razmere popravili oziroma izboljšali.

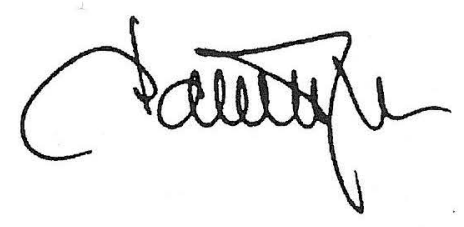

